\title{
The Effectiveness of Local Wisdom Based on Textbook to Improve Students' Writing Literacy
}

\author{
S. Sujinah ${ }^{1, *}$, Muhammad Arfan Mu'ammar ${ }^{2}$, Ali Nuke Affandy ${ }^{1}$, Eko Supriyanto ${ }^{3}$ \\ ${ }^{1}$ Department of Indonesian Language and Literature Education, Faculty of Teacher Training and Education, Universitas \\ Muhammadiyah Surabaya, Jawa Timur, Indonesia \\ ${ }^{2}$ Department of Islamic Education, Faculty of Islamic Studies, Universitas Muhammadiyah Surabaya, Jawa Timur, Indonesia \\ ${ }^{3}$ Faculty of Teacher Training and Education, Universitas Muhammadiyah Surakarta, Jawa Tengah, Indonesia
}

Received August 16, 2019; Revised October 30 2019; Accepted November 8, 2019

Copyright $\odot 2019$ by authors, all rights reserved. Authors agree that this article remains permanently open access under the terms of the Creative Commons Attribution License 4.0 International License

\begin{abstract}
Writing skills are quite complex problems in Indonesia and even the world. Writing is closely related to reading, because to be a good writer, they should have a good capability in reading. Meanwhile, the problems faced by Indonesian people at this time are low in reading interest and motivation also the availability of adequate textbooks. The instruction of writing practice is delivered orally by teachers and certainly the result is not optimum. The purpose of this study is to describe the effectiveness of literacy textbooks. The effectiveness of literacy text books is seen from two aspects, namely students' learning outcomes in the form of product (textbook) of children stories are based on the "local wisdom" and students' responses to the application of textbooks in the learning process. From the results of data analysis, it can be concluded that the ability of students in understanding the literacy textbooks is quite good. These results are obtained from the products produced by the students in the form of short story scripts. The findings of this study showed that the ability to use the Indonesian spelling was still low and need to be improved, because the fact that reported speech produced by students are not in line with the rules. In addition, the story line in the children texts is still flat. Whereas, the students' responses on the effectiveness of text books are in the "good" category. The students are very interested in using of 'literacy' textbooks to write children's story scripts based on the "local wisdom and cultivation of character" because they have the opportunity to produce a children's story script. They even asked for the additional time and suggested that the teaching of Indonesian spelling material to be inserted in the chapter of the 'literacy' textbooks.
\end{abstract}

Keywords Effectiveness, Literacy, Local Wisdom, Cultivation of Character

\section{Introduction}

From the progress of data in International Reading Literacy Study (PIRLS) and the Program for International Student Assessment (PISA), especially in reading comprehension skills show that the competence of learners in Indonesia is very low. The finding is line with the findings of the UNESCO (2012) that the reading habits of Indonesian society that is just one of 1,000 people who read (Wiyatmi \& Suryaman, 2015). This is indeed a serious problem reflecting the fact that the ability and skill of reading are the foundation for gaining knowledge, skills, and attitudes. Besides, this low reading skill also indicates that educational processes have not developed the competencies and interests of learners towards knowledge acquisition yet. Students' literacy skills are also influenced by the teaching experience, support organizations and initiatives or creativity of teacher. This is based on the results of research in the Philippines by Gabinete who studied in three public school teachers, found that professional teachers need to be given special training in teaching and assessing literacy skills especially visual literacy and need to get support from the government (Gabinete, 2017). Meanwhile, the results of American and Pouromid studies (2018) on learning materials showed that there are differences between Iran and Japanese teachers in terms of managing the learning materials. The confidence of Iranian teacher's in managing the learning materials is rooted in their experience of the syllabus and learning in addition to the standard-setting context. On the other hand, Japanese teachers see teaching material as mediating learning experience and self-developed theory and inspiration from colleagues. Further Iranian teachers state that other parties are also responsible for pedagogical decisions and in terms of learning materials are no exception. While a large part of the Japanese teachers 
themselves are responsible for decisions to use teaching materials. The Increasing of failure in reading and writing among student in Swedish schools produce that many students cannot reach the goal that in stated in the curriculum in compulsory school (Swärd, A.-K.: 2013).

The challenges and problems faced by Indonesian people are undoubtedly in the low interest of people in reading and motivation in reading, and also the availability of books. Whereas in the current global era, people are required to have the ability to understand the text analytically, critically and reflectively, those are an ability to seek, understand and critically evaluate, and also manage the information become knowledge that is useful for personal and social development. Therefore, literacy is very important. This is a way for community (learners) to recognize, understand, and apply the knowledge in life (Christiansen \& Bertram, 2019).

Writing skill is the most difficult skill of the four other skills (Naghdipour, 2016; Swärd, 2013). However, in order to write well, ones must do a lot of reading (Williams \& Lowrance-Faulhaber, 2018). Therefore, to be able to write a script of children story, university students should read the manual in this case literacy textbook which in this study is developed by the researcher. This will be a new method considering the existing method has students write the story based on lecturers' verbal instructions. Undoubtedly, this study aims to elicit the student's responses to the implementation of that literacy textbook and its impact on the ability of students to write a script based on children stories of local wisdom that function as a medium for the cultivation of character.

\section{Literature Review}

Considerable literacy studies have been made inside and outside Indonesian context. In Indonesia, one of the studies is from (Elola \& Oskoz, 2017) which showed that a book is not simply as a referral in writing but also as a medium for critical thinking by discussing the meaning not only the surface meaning. In this way, literacy students' writing in the lecture is not passive, but active, critical and very dialogical. It departs from the concept that literacy is the axis improving the quality of human life, because literacy is the axis of the eddies of education (Bradbury, 2014). Education which centers in reasoning power ability to think logically, information processing skills of reading, and the ability to conclude with the own language or thought. The concept of reason, actually closely linked with literacy is not only limited to the ability to read and write, but also relates to interpret the text (such as letters, numbers, and cultural symbols) (Shao \& Purpur, 2016)(Davidson, 2019).

Baswedan (2018) further points out that literacy is one of the skills that must be possessed by every person in the 21 st century, in addition to character and competence. Literacy should be owned by every person including basic literacy which includes basic writing and reading, numeracy, science, information technology and communications, financial, culture and citizenship. Besides, the main characters which must be had by every human in the face of the unpredictable changing environment, among others are faith and piety, curiosity, initiative, persistence, adaptability, leadership, social and cultural awareness, along with critical thinking / problem solving, creativity, communication, and collaboration (Gardiner, 2017). Hence, university students as a forerunner of the nation's future will not be competitive if they are not trained in $21 \mathrm{st}$ century life skills. One of the ways to help solve the nation's main growing moral character in children namely through administering the habit of writing the script children story. The proposed way is also a part of avenue to apply students' knowledge gained through reading text books which are then applied in the context of real life in the form of writing.

Research conducted by Sujinah entitled "Gender Comparison in Indonesian Student Literacy Achievement" demonstrated that in general, female students scored average higher in literacy than females (Sujinah, 2016). The difference is 40 points mainly in Finlandia, Austria, Germany, Iceland, Norway, Poland, Serbia, Austria and Thailand. Furthermore, another difference literacy reading between female and male learners is in Indonesia, taken form the result of PISA 2000 and PISA 2003. It showed that female learners are better than male because female learners got 16 points while male only gained 11 points and this is at the level of lowest literacy. Besides, the difference in terms of achievement between boys and girls are the smallest, such is in Korea, the Netherlands, and Macao-China. Research that conducted by Sujinah (2016) with the title of Students Attitudes towards Cultural Literacy in Schools using a case study showed that the students are very enthusiastic about the implementation of literacy culture in schools conducted using techniques sustained silent reading. Enthusiasm is more visible when the students determine the books that they want to read. This is due the fact that students have more freedom to choose the books of their interests in to be more effective. This certainly applies to the education units where the literate cultures have been entrenched. Cultural literacy can be called to have been embedded in learners if the learners can still read anywhere and at any time initiatively.

Wekke (2016) further found that the average proportion of reading culture among students of high school graduate in Germany read 32 titles of books, in the Netherlands 30 books in Russian 12 books, in Japan 15 books, Singapore 6 books, in Malaysia 6 books, Brunei 7 books, while Indonesia 0 books. Furthermore, World Bank in its report on education in Indonesia Education: From Crisis to Recovery (1998) reveals that the reading ability of six grades in Indonesia scored 51.7. Other countries such as Hong Kong scored 75.5, Singapore with a value of 74.0, 65.1 Thailand, and the Philippines scored 52.6. These 
results indicate that the Indonesian reading ability is still below compared than other countries. This is confirmed again by the results of an international study (PIRLS) 2006, Indonesia (493) ranks fifth from the bottom, slightly higher than Qatar (356), Quwait (333), Morocco (326), and North Africa (304). In addition, Suryaman's study showed that the average achievement of students' ability in Vincent Indonesia is at a low level below the international median and the ability to solve problems of Indonesian students increase from 2006 to 2011, especially at the level of high, medium, and weak, but at the perfect level there has been no change (Wiyatmi \& Suryaman, 2015).

Hidayat stated that the culture of reading for students in Indonesia is low, which is indicated by the minimal number of visitors who borrow books in the library (Hidayat, Basuki, \& Akbar, 2018). This is because (1) the number of books the library collection is not enough to meet the demands of reading; (2) the tools, equipment, and the librarian are not appropriate; and (3) the school does not allocate a specific budget adequate for library development. Furthermore it is said that the failure of reading culture for students is also influenced by political and social factors include (1) lack of policy (political will) from both national and local government to develop the awareness of literacy of citizens; (2) lack of awareness of citizens about the importance of a culture of reading and writing; (3) the low culture of reading and writing has not been considered as a matter of urgency (critical problem) so it does not immediately get a response quickly, and even tends to be underestimated; (4) Assuming literate culture is only the exclusive consumption of the elite, so that ordinary people feel no need to do it; and (5) a false assumption that building the culture and awareness of literacy is only in the hands of educational institutions, ergo other institutions such as business organizations (companies) or individual has not yet been moved to help build the culture and awareness.

Reading and writing literacy is one of the most important activities in life (Genlott \& Grönlund, 2013). Most of the educational process depends on the ability and awareness of this literacy. Writing give tremendous benefits such as self-entertainment, media information, media delivery opinions, earn, save memory and problem solving. Alwasilah (2012) further said that the implementation of the instilling of the culture of literacy in language learning can be implemented by adhering to the following principles: (1) literacy is a life skills which allows humans to function optimally as a member of society, (2) literacy includes receptive and productive abilities in an effort to discourse in writing or orally, (3) literacy is the ability to solve problems; (4) literacy is a reflection of mastery and cultural appreciation; (5) literacy is the self-reflection; (6) literacy is the result of collaboration; and (7) literacy is an activity of interpretation.

Language learning is an effort to cultivate literacy conducted in four interrelated dimensions as shown in figure 1. Therefore Good language learning must produce literate people who is capable of using four dimension simultaneously, active and integrated; and using language effectively and efficiently (Alwasilah, 2012).

Literacy simultaneously involves all four dimensions (language, cognitive, social, and development) as shown in figure 1. Literacy is the ability to read and write that requires linguistic knowledge and uses mental processes and strategies to produce meaning. In addition, literacy is also a process of "becoming" on an ongoing basis through lifelong education. Teaching literacy means teaching a number of textual and cultural sensitivities across groups and institutions.

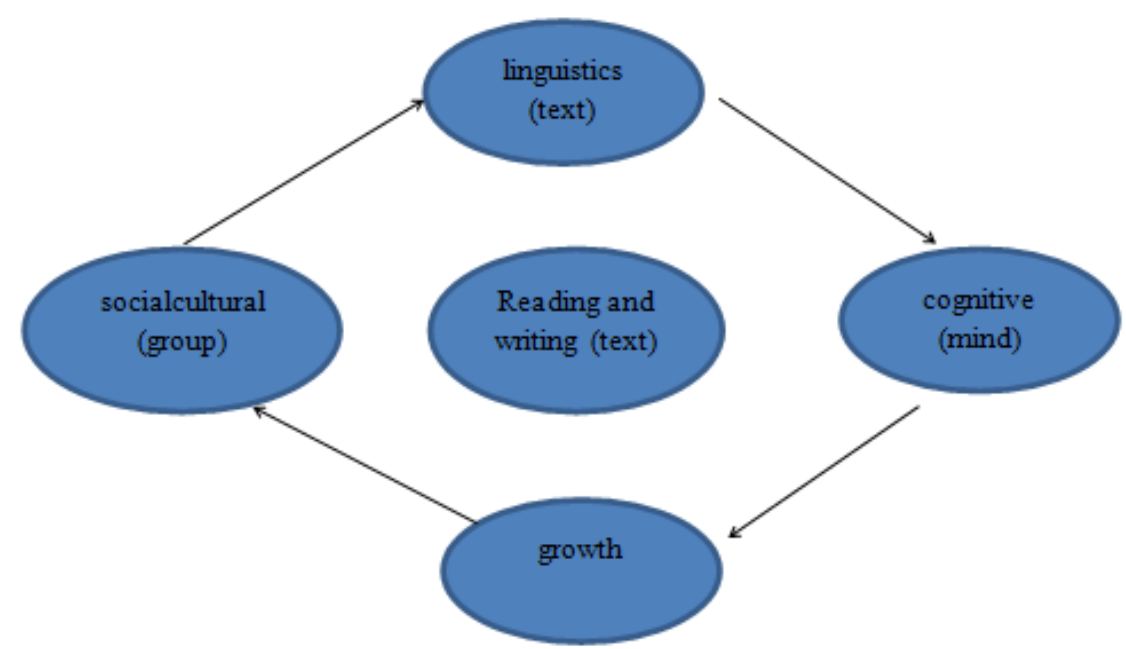

Figure 1. Dimensions of Reading and Writing Literacy 
Table 1. The Shift of Literacy Learning Paradigm

\begin{tabular}{|c|c|}
\hline In the Past & Now \\
\hline Language is an independent structural system & Language is a social phenomenon \\
\hline Learning focus on isolated sentences & Focus on flakes \\
\hline Oriented to results & Interconnecting sentence \\
\hline Focus on the text as a display & Oriented to the process \\
\hline Vocabulary and grammar structures & Focus on the text as a realization of communication actions \\
\hline Prescriptive norms taught in the language & Attention on the variation of the register and style of utterances \\
\hline Focus on the acquisition of skills separately (discrete) & Focus on self-expression \\
\hline Emphasizing denotative in context & Emphasizing the value of communication \\
\hline
\end{tabular}

(Source: Kern, 2000: 19)

Table 1 describes that the changes in the literacy learning paradigm has a number of consequences for learning methods and techniques and measured results. For example, the orientation changes from result to process. The problem is not how much writing students produce and setting the same target for all students, but how the writing is processed creatively according to hobbies, style and self-expression. Spelling errors are corrected over time, as long as students express their writing (Kern, 2000)

Language is a medium for the creation of literary works that cannot be ignored. This implies a close proximity between language skills and penchant for literary reading. Considerable studies were conducted whose results showed that learners who high language skills are students who read a lot of literature (Hairul, 2014). The relationship between the habit of reading and increased intelligence about the language can be a decent reading material for learners in an effort to cultivate literacy. According to Sujinah (2016) that "literacy is the heart of a student's ability to learn and succeed in school and beyond. Therefore, it is essential that every student from preparation to Year 12 the best chance to master literacy so they can meet the challenges of 21 st century life. Furthermore, it is said that the priority of education is to enable all students to progress to higher literacy standards, taking into account their diverse circumstances. Although the background of learners is different, the efforts still should be made so that the learners get a level of literacy adequate for the challenges of the 21st century.

They realized that literacy begins with the high quality of literacy learning which as the key to the success of students in the future (Puranik, Phillips, Lonigan, \& Gibson, 2018). Learning literacy is an integral learning, so it takes good quality of learning in all subjects (Christiansen \& Bertram, 2019). At school, every learner is challenged to read a number of books in a given time. Research shows that one of the best ways to achieve this goal is to provide books that are preferred and desirable for students (Gu, $\mathrm{Wu}, \& \mathrm{Xu}, 2015)$.

Textbook is one book that serves to equip students to have writing competency (Gericke, Hagberg, \& Carvalho, 2014)(Lee, 2018), especially writing the script of children based on local wisdom. Children stories which are written by university students as a result of reading and writing literacy are expected to serve as a means of growing character. The growth can be grown not only through education in a family but also through story books which are read by the children. Character building is a habituation activity increasing positive attitude and behavior at school. Habituation is a series of activities to be undertaken by students, teachers and education personnel aimed at cultivating good habits and form a positive character generation. Building character aims to (a) make the school as a fun learning place for students, teachers and education personnel; (b) develop good habits as a form of character education in the family, school, and community; (c) make education a movement involving government, local government, community, and family; and / or (d) foster the learning harmonious environment and culture of family, school, and community (Kemendikbud, 2015). The implementation of the growth of manners based on the consideration that people mostly neglect the implementation of the basic values of humanity stemming from five principles of Indonesia which is still limited only in understanding of the value in the conceptual level, yet not to actualize the values with fun things in the school environment, family, and community. The target of character growth is for the primary school learners who are in a transitional period of time to play. Thus, by reading a children book developed by this study is expected to contribute to the development of the next generation ( $\mathrm{Gu}$ et al., 2015).

In the development of local wisdom-based literacy books, that is all forms of knowledge, belief, understanding or insight, as well as customs or ethics that guide human behavior in life in an ecological community. The local wisdom of a society can be understood as a value that is considered to be good and true that lasts for generations and implemented by the relevant public as a result of the interaction between man and his environment. In this era, 
globalization turns the world to be more complex. Children's social life as a cyborg attached to the digital space from the virtual game television, video, and computer rather than connected with their local places. The impact of this change (Wason-Ellam, 2010),

While the forms of local knowledge in the community can be values, norms, ethics, beliefs, customary law and specific rules. The substance can be any local knowledge about the rules (1) institutional and social sanctions; (2) The provisions on the use of space and the approximate season for planting; (3) preservation and protection of the sensitive region, and (4) shapes shelter adaptation and mitigation to climate, disasters or other threats (Ernawi, 2009). Interpreting characters in relation conjunction with local wisdom in which it is highly synergistic. In born and developed cultural roots follow the pattern of the past. In the local wisdom contained system constructed communal values and rooted to arrive at valid normative stable. Therefore, it is not surprising that each region has a different character. This basic reinforcement of these characters must involve the community that supports the culture. Community support is the main one, which move and change with the current developments. Relation with textbooks developed based on local wisdom as a means of literacy write effective enough students for the provision of competence to write the script of a child. Furthermore, the script of a child that has been produced y the students, piloted in primary schools as a growing media / customizing character. However, at this writing is not to measure the influence of the children's book character growth because only limited to the student's response to the textbook literacy and literacy books that measured the effectiveness of students' ability to generate text-based children's stories of local wisdom. After reading the script of children, students were asked to demonstrate or simulate, so that every student got a part to play a role and this is part of the growth that is owned by the learners. Research Hamer et al (2017) using local wisdom to develop textbook English subjects. at this writing is not to measure the influence of the children's book character growth because only limited to the student's response to the textbook literacy and literacy books that measured the effectiveness of students' ability to generate text-based children's stories of local wisdom. After reading the script of children, students were asked to demonstrate or simulate, so that every student got a part to play a role and this is part of the growth that is owned by the learners. While the research conducted by Septy (2016) that the content of local knowledge is used as a learning resource in English teaching with the aim of integrating the communicative competence of students with the development of appropriate character. Setiawan used local knowledge to develop content modules natural science subjects and the result indicates that the modules are appropriate to enhance students' science literacy skills either theoretically or empirically (Setiawan, Innatesari, \& Sabtiawan, 2017), whereas in the study of local wisdom used to write the script of a child.

Children's story produce generated script of literacy students' writing, including short story category (story). Short story is a story complete text read in one sitting, approximately ranging between half and two hours and the short story is a short story that gives the impression of a single dominant and focused on a single character in one situation. A literary work can be classified into a cliff if they meet several characteristics, namely (1) can be read only with a sitting area, (2) no more than 10,000 words and a minimum of 1,000 words, (3) grooved sole, (4) themed single, (5) in a simple portrayal of the character figures, and (6) the conflict is not to change the fate of the characters. Extrinsic elements include the short story author biographies, social conditions, economics, history, etc., and intrinsic elements consist of character and characterization, plot, background, style, narrative, themes, perspectives and mandate (Nurgiyantoro, 2018).

Prominent were the perpetrators of the story. Character / characters are the character and attitude of the characters. A characterization is the way the author presents a character in the story and its characters. The characterization of the character of a work by a writer called dispositive. There are two dispositive presentation techniques, namely direct technique (expository / analytic): drawings could be done by providing descriptions directly by the author or authors and indirect techniques (dramatic): the reader figures out the nature of the characters in the story. Meanwhile for the delineation of character figure can be realized by (1) the dialogue between characters, (2) delineation action figure, (3) your thoughts and feelings of the characters, (4) a stream of consciousness, (5) reactions from other character, (6) delineation background and (7) the physical depiction of figures.

Groove or $\mathrm{t}$ plot is a series of events that continued to connect in a story based on the logic of causation. Based on the type there are (1) the advanced groove: groove stages are presented in a coherent from the beginning (introduction) to the end (completion); (2) backward flow: the flow is presented from late stage (completion or current conditions) are preliminary (introductory or past conditions). Flow is commonly called flashback; (3) the flow forward and backward (mixed): in a paper that there are two grooves at the same forward and backward. Stages groove in a work include (a) the introductory stage: the opening story generally contains character recognition and initial information about the story; (B) the appearance of a conflict phase: the beginning of the conflict; (C) the climax stage: developing and heating the conflict; (D) the stage of anticlimax: the conflict began to subside;

Background is a description of the place, time, atmosphere, and social conditions of the occurrence of the story. The Background is relating to the location of the events in the story, e.g. the park, at school, in the forests, and so on. While the background is related with the current 
time or the timing of events in the story, e.g. morning, afternoon, evening and so on. Background of the atmosphere associated with emotional conditions, e.g. anger, sadness, fear, joy, and so on; and social background: dealing with the circumstances in the story, e.g. customs, culture, norms, and so on. The literary style is the way the author uses language to create the effect of beauty and gives a deep impression on the story.

The theme is the subject of the underlying story and a message is the message of the author through the story. Theme of the story is based on the basic values of humanity that includes national and habituation to grow (1) the values of the internalization of moral and spiritual dispositions; (2) persistence keeping the national spirit and diversity to glue the unity of the nation; (3) maintain a school environment, namely conduct collaboration to maintain security, order, comfort, and cleanliness of the school environment; (4) positive social interaction among learners; (5) the positive social interaction among learners with the figure of an adult; (6) an appreciation of the uniqueness of the potential learners to develop; and (7) the strengthening of the role of parents and the public concerned,

Storytelling or point of view is the position of the author in describing the story. The point of view includes a first person perspective and third-person perspective. First-person perspective is the main actors characterized by the use of the pronoun "I" on the main actors and viewpoints additional actors characterized by the use of the pronoun "I" in additional actors are fully communicating. While figure was a third person perspective is the author is in outside the story. The third-person perspective to distinguish between three limited point of view which is characterized by using the pronouns he, she, they, or the name of the character. The third-person perspective omniscient marked using pronouns he, she, they, or the name of the character.

\section{Research Methods}

This research is a quantitative descriptive research. The data collection technique used was a questionnaire and a test product in the form of text stories of children based on local wisdom and growth of character.

\subsection{Research Subjects}

In this study, the research subjects were 22 students of the fourth semester of Indonesian Language Education and Letter Department in one private university in Indonesia.

\subsection{Data Analysis}

The data of questionnaire were in the form of words, sentences, or phrases in which is analyzed using descriptive analysis techniques. Besides, for the closed questionnaire, it was analyzed using a Likert scale (Usman \& Akbar, 2011).

\section{Finding and Discussion}

\subsection{Research Result}

\subsubsection{Student Response to the Textbook Literacy Developed}

In the questionnaire, the student responses were about the use of textbook to develop literacy. The literacy text book entitled child literacy and local wisdom: the development of good character at the stage of the main field testing as one step in the research was the development of teaching practices in literacy script writing children's stories. Teaching practice was performed to data on the effectiveness of textbooks. In the discussions, based on the research objectives, presented the student response to the implementation of literacy textbooks, and descriptions of students' ability to produce the script of a children story.

\subsubsection{Students' Responses to the Implementation of the Textbook Literacy}

Students' responses to the implementation of literacy textbooks in teaching writing for children were measured by using a questionnaire that included open four questions / statements and one closed questions. Questionnaire submitted in the online form to avoid subjectivity as student names are not detected, so that the students were free and flexible in giving his opinion. Fourth-item questions or statements were open-ended, namely (1) how was the quality of the implementation of textbooks, (2) the delivery of content, (3) the covering of material, and (4) has the implementation of the textbook in the process of learning equipped students to create a script of children story.

The following responses were generated from each of four open-ended questions. The first item related to the quality of text books developed implementation, data as shown in the following chart.

Figure 2: "the quality of the implementation of the textbook " in script writing children's stories on the implementation of the main phase of field testing showed that the students choose number 4 (good) at most at $63.6 \%$ while the choose a score of 5 (excellent), i.e. $36.4 \%$. While responding to the numbers 1,2 , and 3 are no. Thus, the first item was related to the quality of a good implementation phase (4.4). Respondents facilitated so no complaints dissatisfaction. 


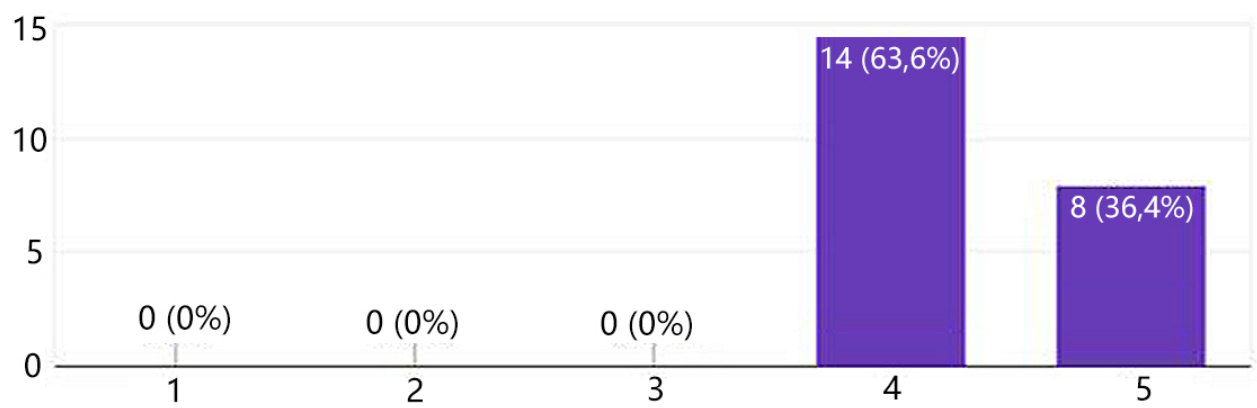

Figure 2. Student Response to the Quality Learning

The response of respondents to the second questionnaire item, which is related to "the quality of the delivery of content" in the implementation of the script writing children's stories got a response of $68.2 \%$ quality delivery of content "good quality" and $31.8 \%$ qualified "very good".

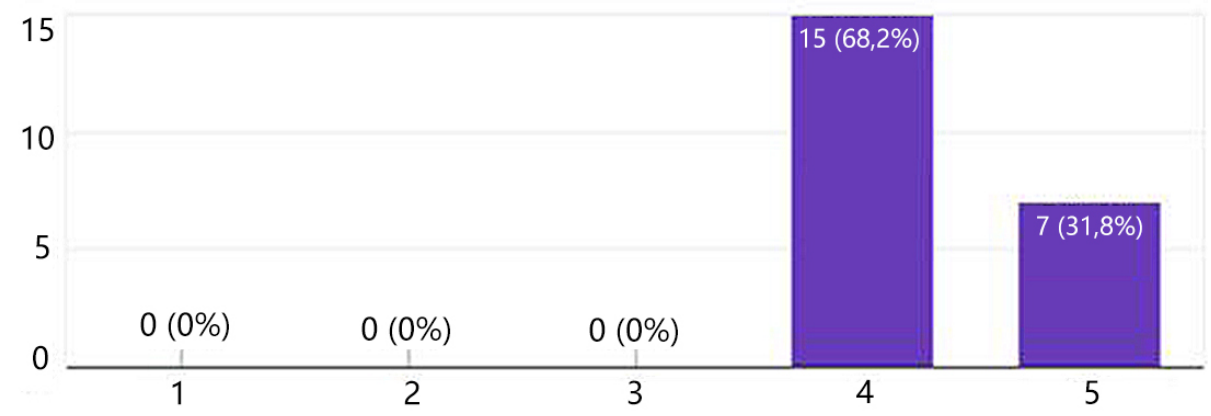

Figure 3. Quality Delivery of Content

The figure shows that the quality of the transmitter of the material included into the category of a good result, which averaged a good result (4.3). No respondents had a very poor category (1), less (2), and sufficient category (3).

The third item, the "material" which was delivered in implementation received a response from the respondents 59.1\% said good, and $40.9 \%$ said very good. Below is a graph of the respondents' statements.

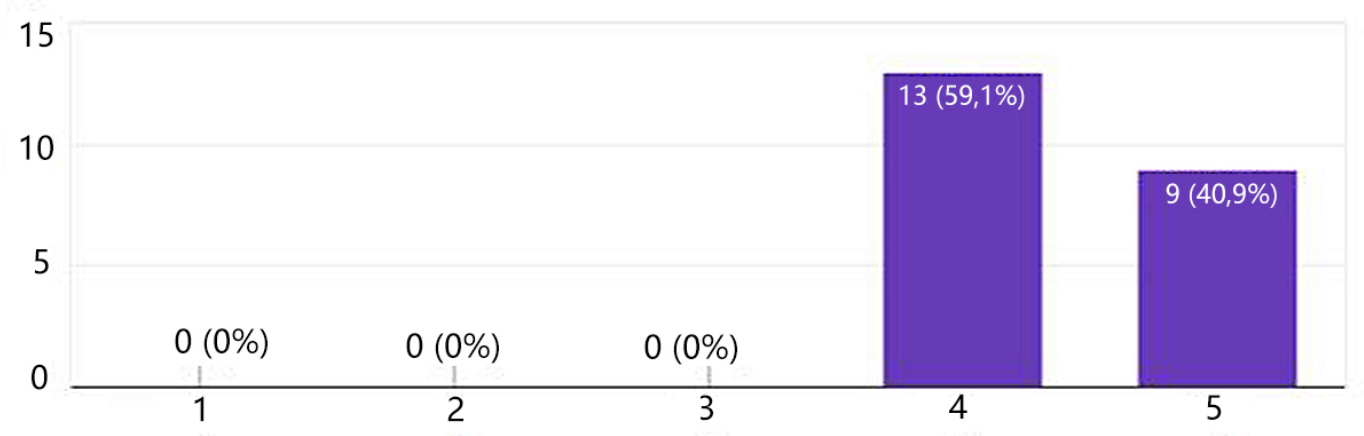

Figure 4. Quality of the Materials 
Figure 4 above states that the material contained in textbooks developed $59.1 \%$ expressed either by the respondent. The response states "matter" in the very good category amounted to $40.9 \%$. If averaged the responses were obtained in the category of "good" (3.95).

This Statements regarding the material responded "good" is in line with the response to the four-item questionnaire, which asks "whether enough material to write a script to equip the children's stories based on local wisdom". Related to this question, $59.1 \%$ of respondents stated $40.9 \%$ stated sufficient funds are not enough. In average, the response obtained in the category of "good" (3.95). The following chart states that the material in the book is enough to equip students how to write children story scripts.

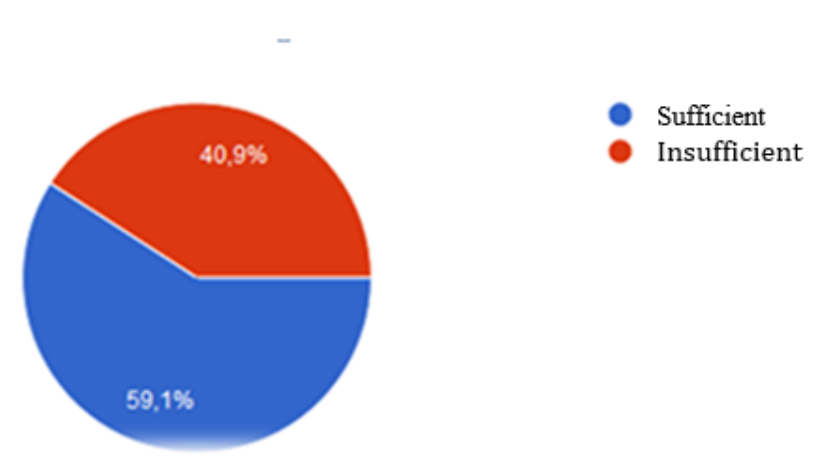

Figure 5. Adequacy Material in Textbooks Developed

In addition to the response to the fourth item, respondents were also asked to provide suggestions on the implementation of textbook learning. The suggestions submitted by respondents varied from one to another, but they were still constructive. Even respondents who that delivery of content is very good and not long-winded, but some are suggested that the material character plus. In addition, nearly $35 \%$ of respondents want a plus. The advice referred to the need for additional time to complete the script writing children's story based on local wisdom as a medium for the growth of character.

The following suggestions were submitted by respondents who presented regarding the implementation of literacy textbooks in teaching script writing children's stories based on local wisdom.

Table 2 is the result from data collection through a questionnaire containing comments and suggestions. The data collection is gained through the questionnaire which contains comments and suggestions. Based on the respondents' responses, the researcher classified them into two aspects, namely aspects of comments and advices, as shown in the table. Based on the comments aspect, the respondents generally stated that the material and delivery were good, qualified and very useful (learning). Whereas from the suggestion aspect the respondents wanted (1) to carry out that similar activities since it really helps them to sharpen their writing skills and (2) to follow up the learning activities with further training. Table 2. Comments and Suggestions Respondents on the
Implementation of the Textbook

\begin{tabular}{|c|c|}
\hline ASPECT & DESCRIPTION \\
\hline \multirow{9}{*}{ COMMENT } & Extraordinary \\
\hline & Already both in facilities \\
\hline & Submission is easy to understand \\
\hline & Submission pretty good \\
\hline & Nice delivery \\
\hline & It is enough \\
\hline & Alhamdulillah outstanding \\
\hline & helpful once \\
\hline & Alhamdulillah, learning / training is very useful \\
\hline \multirow{14}{*}{ SUGGESTION } & The speaker increased so much of a view \\
\hline & More timely delivery of material \\
\hline & $\begin{array}{l}\text { It might be worthwhile if there is operator } \\
\text { (presumably moderator) }\end{array}$ \\
\hline & $\begin{array}{l}\text { Q \& Java and dialogue long enough (meaning } \\
\text { less long) }\end{array}$ \\
\hline & $\begin{array}{l}\text { Facilitator Thank God has been good. However, } \\
\text { timing is also considered. }\end{array}$ \\
\hline & $\begin{array}{l}\text { There was a follow-up to the script of the child } \\
\text { so }\end{array}$ \\
\hline & Delivery of material on schedule \\
\hline & return time is not too late \\
\hline & $\begin{array}{l}\text { More organized similar activities as it helps us } \\
\text { in writing }\end{array}$ \\
\hline & $\begin{array}{l}\text { Implementation of any earlier time to be more } \\
\text { efficient }\end{array}$ \\
\hline & There is training again after this \\
\hline & Organized again gradually and continuously \\
\hline & Fixed constancy in delivering useful knowledge \\
\hline & $\begin{array}{l}\text { It is expected that no follow-up of learning / } \\
\text { training this }\end{array}$ \\
\hline
\end{tabular}

See the response given, it appears that students have an interest in writing children's stories. Suggestions submitted a very positive and constructive. Training script writing children's stories should be followed up so that the product is good. Seeing the positive response from the students, the training / learning literacy write the script of this child will be followed by a review and mentoring to be produced scripts worthy of publication. To produce work that everyone needs support, not least the students. The same thing was found in Bingham et al study conducted in three countries in America concluded that students who get support from the teacher writes showed stronger writing skills than students who received less support (Bingham, Quinn, \& Gerde, 2017; Chen \& Myhill, 2016).

Furthermore, the script generated from the writing literacy will be piloted in schools to get a response from the learners and educators so that texts of this story could play a role in fostering learners' manners that had to be nurtured from an early age. Growth character is a part of character education should be done at an early age. During this 
period the growing efforts are commendable behavior to be performed on children, good behavior in worship, behavior as good citizens, the behavior of interacting with other people and the environment, and commendable behavior is beneficial to the success of his life (Khaironi, 2017),

\subsubsection{Students' Ability to Write the Script of a Child}

The implementation of these textbooks was attended by 22 students. To see the effectiveness of the book, the necessary evaluation of its implementation in the form of learning outcomes is needed. Learning outcomes expected performance in this case in the form of script of children story based on the local wisdom. The try-out then carried out to know whether the book developed was effective based on students' performance script of children story. Here is presented the results of student performance in the form of script assessed children story of empty (4) aspects.

Based on data obtained through the product test in the form of a children story, it is known that the ability to write an average of 74 students means included in both categories. The resulting script of children stories made by students in both categories, with details that student power sequentially from the aspect of the content of local knowledge (22.32), aspect of the conflict (18.77), aspects of the storyline (18.64), although still found some scripts less conflict still "flat". Meanwhile, from the aspect of language score (14.36) the lowest score compared with three other aspects. Aspects of language are still many errors that the writing paragraphs, writing sentences without subjects, and punctuation including capital lettering. Writing capital letters that many mistakes made by the students is the use of capital letters in the sentence immediately. Local knowledge is the central feature in the script of this child, because they local knowledge is quite interesting content to be developed both in the development of textbooks, modules, and in the script of the child. This is evidenced by the highest score on the script of a child who is the result of students' writing literacy.

Table 3. Script Writing Ability of Children Story Based on the Local Wisdom

\begin{tabular}{|c|c|c|c|c|c|c|}
\hline \multirow[b]{2}{*}{ No. } & \multirow{2}{*}{ Respondents } & \multicolumn{4}{|c|}{ ASSESSMENT CRITERIA } & \multirow{2}{*}{$\begin{array}{l}\text { Total } \\
\text { Scores }\end{array}$} \\
\hline & & Conflicts $(25 \%)$ & $\begin{array}{l}\text { Plot } \\
(25 \%)\end{array}$ & Language (25\%) & Local Wisdom (25\%) & \\
\hline 1 & A & 20 & 20 & 10 & 25 & 75 \\
\hline 2 & B & 25 & 10 & 10 & 25 & 70 \\
\hline 3 & $\mathrm{C}$ & 10 & 25 & 10 & 25 & 70 \\
\hline 4 & $\mathrm{D}$ & 10 & 20 & 20 & 22 & 72 \\
\hline 5 & $\mathrm{E}$ & 15 & 15 & 18 & 20 & 68 \\
\hline 6 & $\mathrm{~F}$ & 20 & 15 & 20 & 22 & 77 \\
\hline 7 & G & 20 & 20 & 20 & 20 & 80 \\
\hline 8 & $\mathrm{H}$ & 8 & 25 & 15 & 25 & 72 \\
\hline 9 & I & 15 & 10 & 15 & 25 & 65 \\
\hline 10 & $\mathrm{~J}$ & 20 & 20 & 20 & 20 & 80 \\
\hline 11 & $\mathrm{~K}$ & 20 & 20 & 20 & 25 & 85 \\
\hline 12 & $\mathrm{~L}$ & 20 & 20 & 20 & 25 & 85 \\
\hline 13 & M & 15 & 20 & 15 & 20 & 70 \\
\hline 14 & $\mathrm{~N}$ & 15 & 20 & 20 & 25 & 80 \\
\hline 15 & $\mathrm{O}$ & 25 & 25 & 15 & 20 & 85 \\
\hline 16 & $\mathrm{P}$ & 25 & 25 & 15 & 25 & 85 \\
\hline 17 & Q & 20 & 25 & 15 & 25 & 85 \\
\hline 18 & $\mathrm{R}$ & 25 & 15 & 15 & 20 & 75 \\
\hline 19 & S & 25 & 25 & 18 & 20 & 88 \\
\hline 20 & $\mathrm{~T}$ & 20 & 25 & 10 & 25 & 80 \\
\hline 21 & $\mathrm{U}$ & 20 & 20 & 15 & 20 & 75 \\
\hline 22 & $\mathrm{~V}$ & 20 & 20 & 20 & 20 & 80 \\
\hline \multicolumn{2}{|c|}{ Average } & 18.77 & 18.64 & 14.36 & 22.32 & 74.18 \\
\hline \multicolumn{6}{|c|}{ Average } & 74 \\
\hline
\end{tabular}


This is in line with a similar research conducted by Pinto et al (2016) to 122 Italian children on the ability to rewrite oral stories into written form. Assessment is done twice, the first time the end of the year in kindergarten and one year later when the students in the first grade of primary school. After linear regression analysis showed that the literacy variable is significant narrative structure of the story, while the other variables such as phonology, writing conceptual knowledge such as coherence and cohesion are less significant(Pinto, Tarchi, \& Bigozzi, 2016), Shamir et al study on younger children in Hebrew, indicating that the progress of literacy (reading the word and write the word) can be improved by reading e-books, while naming the letters cannot be improved (Korat, Shamir, \& Segal-Drori, 2014),

\section{Conclusions}

Based on the data analysis of students' responses on the implementation of literacy textbooks during the learning process, it is divided into two aspects, those are comments and suggestions. The commentary aspect stated that the material and its delivery were in good and qualified categories, and the learning activities were very useful. From the suggestions aspect, the respondents wanted (1) to do similar activities because they really helped them sharpening their writing skills and (2) to follow up the learning activities with the implementation of textbooks with sufficient time.

The results of the ability to make a children story script as an indicator of the effectiveness of the literacy textbooks got an average score of 68 and regarded as a fair category. The children story scripts need to be followed up in the form of mentoring, especially in the aspect of story lines that are still flat, the subject in the sentences were sometimes missing and the use of capital letters were still incorrect, especially in the reported sentences. These are the inputs for improving the textbooks developed because the materials related to writing skills (paragraphs, sentences, and spellings) had not included yet.

\section{Acknowledgements}

This research was funded by Directorate of Research and Community Service, Unemployment Research Scheme of Higher Education, Indonesian Ministry of Research Technology and Higher Education, with Contract No. SP DIPA-NOMOR 113/SP2H/LT/DRPM/2019.

\section{REFERENCES}

[1] Alwasilah, A. C. (2012). Pokoknya rekayasa literasi.
Bandung: Kiblat Buku Utama.

[2] Amerian, M., \& Pouromid, S. (2018). Language teachers' beliefs on materials use and their locus of control, casestudies from Iran and Japan. Indonesian Journal of Applied Linguistisc, 7(3), 9. https://doi.org/10.17509/ijal.v7i3.9808

[3] Baswedan, Anies. 2018. Utamakan Karakter dalam Pendidikan.https://www.youtube.com/watch?v=6StVO7m deio

[4] Bingham, G. E., Quinn, M. F., \& Gerde, H. K. (2017). Examining early childhood teachers' writing practices: Associations between pedagogical supports and children's writing skills. Early Childhood Research Quarterly. https://doi.org/10.1016/j.ecresq.2017.01.002

[5] Bradbury, K. S. (2014). Teaching Writing in the Context of a National Digital Literacy Narrative. Computers and Composition, 32, 54-70. https://doi.org/10.1016/j.compco m.2014.04.003

[6] Chen, H., \& Myhill, D. (2016). Children talking about writing: Investigating metalinguistic understanding. Linguistics and Education, 35, 100-108. https://doi.org/10. 1016/j.linged.2016.07.004

[7] Christiansen, I., \& Bertram, C. (2019). Early schooling teachers' learning from a formal teacher development programme in South Africa. International Journal of Educational Development, 66(September 2018), 78-87. https://doi.org/10.1016/j.ijedudev.2019.01.004

[8] Davidson, A. (2019). Writing: the re-construction of language. Language Sciences, 72, 134-149.https://doi.org/ 10.1016/j.langsci.2018.09.004

[9] Elola, I., \& Oskoz, A. (2017). Writing with 21st century social tools in the L2 classroom: New literacies, genres, and writing practices. Journal of Second Language Writing, 36(April), 52-60. https://doi.org/10.1016/j.jslw.2017.04.00 2

[10] Ernawi. (2009). Kearifan Lokal Dalam Perspektif Penataan Ruang. In Seminar Nasional Kearifan Lokal Dalam Perencanaan dan Perancangan Lingkungan Binaan. Malang: Arsitektur Unmer.

[11] Gabinete, M. K. . (2017). Teachers' beliefs and practices in assessing the viewing skill of ESL Learnings. Indonesian Journal of Applied Lungistics, 7(1), 26.

[12] Gardiner, P. (2017). Rethinking feedback: Playwriting pedagogy as teaching and learning for creativity. Teaching and Teacher Education, 65, 117-126. https://doi.org/10.10 16/j.tate.2017.03.009

[13] Genlott, A. A., \& Grönlund, Å. (2013). Improving literacy skills through learning reading by writing: The iWTR method presented and tested. Computers and Education, 67, 98-104. https://doi.org/10.1016/j.compedu.2013.03.007

[14] Gericke, N. M., Hagberg, M., \& Carvalho, V. (2014) Conceptual Variation or Incoherence? Textbook Discourse on Genes in Six Countries, 381-416. https://doi.org/10.100 7/s11191-012-9499-8

[15] Gu, X., Wu, B., \& Xu, X. (2015). Design, development, and learning in e-Textbooks: what we learned and where we are going, 2, 25-41. https://doi.org/10.1007/s40692-014-00239 
[16] Hairul, M. (2014). Reading Emergency Zone (REZ): Miniatur gerakan literasi di sekolah dan alternatif pengembangannya. In Seminar Nasional Plus : Membangun Peradaban Generasi Emas melalui Literasi. Surabaya.

[17] Hidayat, M. H., Basuki, I. A., \& Akbar, S. (2018). Gerakan Literasi Sekolah di Sekolah Dasar. Jurnal Pendidikan: Teori, Penelitian, Dan Pengembangan, 3(6), 810-817. https://doi.org/10.17977/jptpp.v3i6.11213

[18] Hamer, Welliam and Evenddy, Sutrisno S. 2017. Involving local wisdom as values to develop english for tourism course material: A case of Baduy Tribe in Lebak Banten. The Journal of English Language Studies. 2 (1), 92-107.

[19] Kemendikbud, R. I. (2015). Penumbuhan budi pekerti. Jakarta: Kementerian Pendidikan dan Kebudayaan.

[20] Khaironi, M. (2017). Pendidikan karakter anak usia dini. Jurnal Golden Age Universitas Hamzanwadi.https://doi.or g/10.29408/GOLD AGE.V2I01.546

[21] Korat, O., Shamir, A., \& Segal-Drori, O. (2014). E-books as a support for young children's language and literacy: The case of Hebrew-speaking children. Early Child Development and Care. https://doi.org/10.1080/03004430. 2013.833195

[22] Kern, R. 2000. Literacy and Language Teaching. Oxford University Press. Oxford.

[23] Lee, K. (2018). Changes in Attitudes Towards Textbook Task Modi fi cation Using Confrontation of Complexity in a Collaborative Inquiry : Two Case Studies, 343-361.

[24] Naghdipour, B. (2016). English writing instruction in Iran: Implications for second language writing curriculum and pedagogy. Journal of Second Language Writing, 32, 81-87. https://doi.org/10.1016/j.jslw.2016.05.001

[25] Nurgiyantoro, B. (2018). Sastra Anak: Pengantar Pemahaman Dunia Anak. (N. Rosyidah, Ed.) (digitalisa). Yogyakarta: Gadjah Mada University Press. Retrieved from https://books.google.co.id/books?id=ZZtjDwAAQBAJ\&pri $\mathrm{ntsec}=$ frontcover\&hl=id\&source=gbs_ge_summary_r\&cad $=0 \# \mathrm{v}=$ onepage $\& \mathrm{q} \& \mathrm{f}=$ false

[26] Pinto, G., Tarchi, C., \& Bigozzi, L. (2016). Development in narrative competences from oral to written stories in five- to seven-year-old children. Early Childhood Research Quarte rly. https://doi.org/10.1016/j.ecresq.2015.12.001

[27] Puranik, C. S., Phillips, B. M., Lonigan, C. J., \& Gibson, E. (2018). Home literacy practices and preschool children's emergent writing skills: An initial investigation. Early Childhood Research Quarterly, 42(May 2016), 228-238. https://doi.org/10.1016/j.ecresq.2017.10.004

[28] Septy, A. P. (2016). Managing local wisdom in english teaching materials, (20), 81-88.

[29] Setiawan, B., Innatesari, D. K., \& Sabtiawan, W. B. (2017). The development of local wisdom -based natural science module to improve science literation of students. Pendidikan IPA Indonesia, 6(1), 49-54. https://doi.org/10. 15294/jpii.v6i1.9595

[30] Shao, X., \& Purpur, G. (2016). Effects of Information Literacy Skills on Student Writing and Course Performance. Journal of Academic Librarianship, 42(6), 670-678. https://doi.org/10.1016/j.acalib.2016.08.006

[31] Sujinah, S. (2016). Sikap peserta didik terhadap pembudayaan literasi melalui sustained silent reading (p. ). Makasar: Unismu.

[32] Swärd, A.-K. (2013). Re-learning in Reading and Writing is it Possible? Procedia - Social and Behavioral Sciences, 69 (Iceepsy), 104-113. https://doi.org/10.1016/j.sbspro.20 12.11.388

[33] Usman, H., \& Akbar, P. S. (2011). Metodologi Penelitian Sosial (2nd ed.). Jakarta: Bumi Aksara.

[34] Wason-Ellam, L. (2010). Children's literature as a springboard to place-based embodied learning. Environmental Education Research, 16(3-4), 279-294. https://doi.org/10.1080/13504620903549771

[35] Williams, C., \& Lowrance-Faulhaber, E. (2018). Writing in young bilingual children: Review of research. Journal of Second Language Writing, 42(December 2017), 58-69. https://doi.org/10.1016/j.jslw.2018.10.012

[36] Wiyatmi, E. S., \& Suryaman, M. (2015). Analisis hasil belajar peserta didik dalam literasi membaca melalui studi internasional (PIRLS). Litera, 14(1), 170. Retrieved from ISSN 1412-2596

[37] Wekke, Ismail Suardi Lubis, Maimun Aqsha. 2016. A Multicultural Approach in Arabic Language Teaching: Creating Equality at Indonesian Pesantren Classroom Life. Sosiohumanika. 6 (2), 295-310

[38] WorldBank. 1998. Indonesia Education in Indonesia from Crisis to Recovery. http://documents.worldbank.org/curate d/en/558971468752104023/pdf/multi-page.pdf 